\title{
EFEKTIVITAS PENGGUNAAN MEDIA FILM DALAM MENINGKATKAN EMPATI PADA NARAPIDANA KASUS KEKERASAN SEKSUAL DI LEMBAGA PEMASYARAKATAN KLAS IIA KARAWANG
}

\author{
Ulba Mega Agustin ${ }^{1}$, Nuram Mubina², Arif Rahman Hakim ${ }^{3}$
}

Email: Ps17.ulbaagustin@mhs.ubpkarawang.ac.id

Fakultas Psikologi Universitas Buana Perjuangan Karawang

\begin{abstract}
Sexual violence is a universal crime. This evil can be found all over the world, at every level of society. One of the factors causing sexual violence is low empathy. This study aims at determining the effectiveness of using film media in increasing empathy in sexual violence inmates in Karawang's Penitentiary class IIA. This study uses a type quasi-experimental with a research design of one group pretest-posttest design. The sample in this research were seven inmates of sexual violence cases. Sampling was conducted by using the purposive sampling technique. The data analysis technique used non-parametric statisticsthe Wilcoxon test with the help of SPSS 24.0 for windows. The results of the analysis show that the value of Sig. of 0.017 $<0.05$, which means $\mathrm{HO}$ is rejected, Ha is accepted. So it can be concluded that film media is effective in increasing empathy in sexual violence inmates in correctional institution class IIA Karawang.
\end{abstract}

Keyword: Empathy, film media, sexual violence inmates

\begin{abstract}
Abstrak
Kekerasan seksual merupakan kejahatan yang universal. Kejahatan ini dapat ditemui di seluruh dunia, pada tiap tingkatan masyarakat. Salah satu faktor penyebab terjadi kekerasan seksual yaitu empati yang rendah. Penelitian ini bertujuan untuk mengetahui efektivitas penggunaan media film dalam meningkatkan empati pada narapidana kasus kekerasan seksualdi Lembaga Pemasyarakatan Klas IIA Karawang. Penelitian ini menggunakan tipe quasi experiment dengan desain penelitian one group pretest-posttest design. Sampel dalam penelitian ini sebanyak tujuh narapidana kasus kekerasan seksual. Pengambilan sampel dilakukan dengan menggunakan teknik purposive sampling. Teknik analisis data menggunakanstatistic non parametric yaitu uji wilcoxon dengan bantuan SPSS 24.0 for windows. Hasil analisis menunjukkan bahwa nilai Sig. sebesar $0.017<0.05$, yang berarti H0 ditolak, Ha diterima. Sehingga dapat disimpulkan bahwa media film efektif dalam meningkatkan empati pada narapidana kasus kekerasan seksual di Lembaga Pemasyarakatan Klas IIA Karawang.
\end{abstract}

Kata kunci: Empati, media film, narapidana kasus kekerasan seksual 


\section{PENDAHULUAN}

Kekerasan seksual merupakan kejahatan yang universal. Kejahatan ini dapat ditemui di seluruh dunia, pada tiap tingkatan masyarakat, tanpa memandang usia maupun jenis kelamin. Kekerasan seksual adalah tindakan yang mengarah ke arah ajakan/desakan seksual seperti menyentuh, memegang, mencium, dan atau melakukan tindakan-tindakan lain yang tidak dikehendaki oleh korban, memaksa korban menonton produk pornografi, gurauan-gurauan seksual, ucapan-ucapan yang merendahkan dan melecehkan dengan mengarah pada aspek jenis kelamin/seks korban, memaksa berhubungan seks tanpa persetujuan korban dengan kekerasan fisik maupun tidak; memaksa melakukan aktivitas-aktivitas seksual yang tidak disukai, merendahkan, dan menyakiti atau melukai orang lain (Poerwandari, dalam Fuadi 2011).

Berdasarkan data yang diperoleh dari Catatan Tahunan Komnas Nasional Anti Kekerasan Terhadap Perempuan (Komnas Perempuan) melaporkan adanya peningkatan jumlah kasus yang terjadi dari tahun 2018 hingga 2019. Jumlah kasus kekerasan terhadap perempuan tahun 2018 sebesar 406.178, pada tahun berikutnya mengalami peningkatan denganjumlah kasus sebesar 431.471. Berdasarkan data-data yang terkumpul tersebut jenis kekerasan terhadap perempuan yang paling menonjol yaitu KDRT/RP (Kekerasan Dalam Rumah Tangga/Ranah Personal). Pada ranah KDRT/RP kekerasan yang paling menonjol adalah kekerasan fisik sebanyak 4.783 kasus (43\%), disusul kekerasan seksual sebanyak 2.807 kasus (25\%), psikis 2.056 kasus, dan ekonomi 1.459 kasus. Pada tahun 2021 Komnas Perempuan mencatat 299.911 kasus sepanjang tahun 2020, di mana kekerasan seksual menempati posisi kedua pada kekerasan ranah pribadi dengan jumlah kasus sebanyak 1.983 (30\%).

Sebagaimana data yang diperoleh dari Pusat Pelayanan Terpadu Pemberdayaan Perempuan dan Anak (P2TP2A) Karawang, mencatat selama tiga tahun terakhir kasuskekerasan seksual di Karawang mengalami peningkatan. Pada tahun 2020 terdapat 22 kasus kekerasan seksual, jumlah tersebut mengalami peningkatan dibandingkan pada tahun-tahun sebelumnya yaitu pada tahun 2019 terdapat 17 kasus dan pada tahun 2018 terdapat 16 kasus. Bentuk kekerasan seksual yang terjadi bermacam-macam di antaranya pelecehan seksual, pemerkosaan, kekerasan seksual terhadap anak, dan pencabulan. Mayoritas yang menjadikorban kekerasan seksual adalah perempuan, sedangkan pelakunya adalah laki-laki. Angkakasus kekerasan seksual merupakan fenomena gunung es, artinya ada banyak kasus kekerasan seksual yang tidak terungkap dan tidak dilaporkan oleh korban (Danes dalam Sulaeman, 2021). Shenk dan Brown (dalam Nurani, 2014) melakukan sebuah studi untuk mengetahui faktor yang menyebabkan terjadinya kekerasan seksual, mereka membagi menjadi dua faktor, yaitu faktor statis dan faktor dinamis. Faktor statis merupakan karakteristik dalam diri pelaku yang tidak bisa diubah, seperti misalnya pengalaman seksual yang menyimpang, tingkah lakuanti sosial, impulsivitas, sexual arousal yang tinggi, dan preokupasi seksual. Sementara faktordinamis merupakan faktor yang responsif atau bisa diubah dengan adanya perlakuan, misalnya seperti distorsi kognitif, keterampilan sosial yang rendah, fantasi seksual yang menyimpang, dan empati yang rendah.

Biasanya dan tragisnya, empati tidak ditemukan pada orang-orang yang melakukan kejahatan-kejahatan paling sadis. Hal ini umumnya ditemukan pada 
pelaku pemerkosaan, pedofil, dan banyak pelaku tindak kejahatan rumah tangga, umumnya mereka tidak mampu berempati (Goleman, 2018). Ketiadaan empati tersebut mengakibatkan mereka tidak mampu merasakan penderitaan korban dan memungkinkan mereka melontarkan kebohongan- kebohongan kepada diri mereka sendiri sebagai pembenaran atas kejahatan mereka. Pembenaran yang dilakukan tersebut mereka tujukan pada diri mereka sendiri sewaktu melakukan kejahatan kepada korban atau ketika bersiap-siap melakukan kejahatannya (Goleman, 2018).

Berdasarkan survei nasional mengenai intervensi untuk pelaku penyerangan seksual di Amerika Serikat, terdapat 87\% - 95\% intervensi yang dilakukan dengan memasukan intervensi empati dalam programnya (Barnet dan Mann dalam Nurani, 2014). Pemberian intervensi empati banyak diberikan karena penelitian menunjukkan bahwa pelaku kekerasan seksual dinilai tidak mampu merasakan dampak yang sudah mereka timbulkan pada korban, tidak menunjukkan penyesalan, meminimalisasi penderitaan korban, dan menyalahkan korban karena perilakunya yang provokatif (Baron, Harkins, \& Beech dalam Nurani, 2014). Selain itu,kekerasan seksual dinilai memiliki dampak yang tidak sederhana bagi korbannya, korban dapat menunjukkan konsep diri yang negatif yaitu menilai dirinya sebagai perempuan nakal dan akhirnya terlibat hubungan seksual beresiko, penggunaan narkoba serta minuman keras (Mubina, 2017).

Berdasarkan hasil wawancara dan observasi yang dilakukan dengan dua orang narapidana kasus kekerasan seksual dan satu orang pegawai di Lembaga Pemasyarakatan KlasIIA Karawang, pada tanggal 3 Maret 2021 menunjukkan bahwa narapidana tersebut cenderung kurang memperlihatkan adanya empati terhadap korban. Mereka tidak mengakui dan tidak merasa bersalah terhadap kasus yang menimpa mereka, mereka beranggapan bahwa penyebab mereka berada di dalam Lapas dikarenakan tindakan dari oknum-oknum tertentu bukan karena kesalahan mereka sendiri. Selain itu, hasil wawancara yang dilakukan terhadap pegawai lapas juga menunjukkan bahwa narapidana kasus kekerasan seksual tersebut terkadang malu untuk menceritakan kejadian sebenarnya sehingga mereka menceritakan seolah-olah mereka tidak bersalah.

Empati sendiri memerankan peran penting dalam menjalin hubungan sosial dalam kehidupan bermasyarakat (Sutanti, 2015). Ditegaskan oleh Rogers (dalam Sutanti, 2015) bahwa empati adalah salah satu unsur kunci dalam menciptakan hubungan interpersonal termasuk dalam proses terapeutik. Oleh karena itu, empati dapat dijadikan sebagai salah satu bagian dari sebuah karakter yang harus ditanamkan pada diri seseorang.

Menurut Davis (dalam Reza \& Widyana, 2019) mengutarakan bahwa empati adalah reaksi seseorang terhadap pengamatannya pada pengalaman orang lain. Definisi empati lebih luas adalah suatu aktivitas untuk memahami apa yang sedang dipikirkan dan dirasakan oleh orang lain, serta apa yang dirasakan oleh orang yang bersangkutan, terhadap kondisi yang sedang dialami orang lain, tanpa yang bersangkutan kehilangan kontrol dirinya (Taufik, 2012). Empati merupakan emosi atau afeksi yang positif. Empati memiliki peranan penting dalam mengatasi masalah yang sedang dihadapi individu terkait sikap dan perilaku terhadap orang lain (Parman, dkk., 2019). Brigham (dalam Parman, dkk., 2019) mengemukakan bahwa orang yang mempunyai empati tinggi lebih berorientasi pada orang lain yang mengalami kesulitan tanpa banyak mempertimbangkan kerugian-kerugian yang 
akan diperoleh seperti pengorbananwaktu, tenaga dan biaya.

Penelitian yang dilakukan oleh Eisenberg (dalam Taufik, 2012) merumuskan bahwa ada beberapa cara untuk mengajarkan empati, salah satunya dengan modeling. Selain orang lain (termasuk orang tua sebagai model), Eisenberg juga menyatakan aktor yang bermain di televisijuga bisa sebagai model. Sejalan dengan itu, Davis (dalam Andayani, 2012) melihat empati sebagai fenomena multidimensional dan telah menganalisanya menjadi empat bagian yang terpisah tetapi saling berhubungan antara satu sama lainnya, yaitu perspective taking, personal distress, fantasy, dan emphatic concern. Perspective taking merujuk kepada kecenderungan atau kemampuan seseorang untuk mengambil perspektif atau sudut pandang orang lain.Personal distress adalah respon yang berorientasi diri sendiri sebagai respon untuk menghadapi situasi interpersonal yang sulit dan dikarakteristikan oleh perasaan personal yang tidak nyaman ataupun kecemasan. Lalu, orang yang memiliki kemampuan fantasy akan menggunakanimajinasi untuk mengalami perasaan dan aksi karakter di dalam film, buku, atau karya kreatif lainnya. Sedangkan Emphatic concern merupakan kemampuan seseorang untuk mengalami perasaan hangat, iba, dan kekhawatiran terhadap orang lain yang sedang melewati pengalamannegatif.

Adanya peningkatan empati dengan menggunakan media film dibuktikan dari hasil penelitian yang dilakukan oleh Auliyah \& Flurentin (2016) terhadap enam siswa menunjukkan bahwa penggunaan media film efektif untuk meningkatkan empati siswa kelas VII SMP. Menurut Jencius (dalam Auliyah \& Flurentin, 2016) pada saat menonton film, individu akan dibawa pada kondisi emosional di film tersebut. Sobur (dalam Oktavianus, 2015) film adalah suatu bentuk komunikasi massa elektronik yang berupa media audio visual yang mampu menampilkan katakata, bunyi, citra, dan kombinasinya. Film menurut Effendy (dalam Oktavianus, 2015) adalah medium komunikasi massa yang ampuh sekali, bukan saja untuk hiburan, tetapi juga untuk penerangan dan pendidikan.

Lebih lanjut, Citra (2020) menyebutkan bahwa penggunaan teknik cinema theraphy efektif untuk meningkatkan empati remaja di Desa Malela Kecamatan Suli. Kemampuan empati dapat diperoleh melalui pembelajaran, yang dapat diajarkan kepada anak-anak atau pun orang lain. Intervensi-intervensi yang diarahkan kepada pembelajaran empati dapat meningkatkan empati (Taufik, 2012). Film dapat menjadi media pembelajaran yang baik bagipenontonnya tidak semata menghibur, film juga mampu menyampaikan pesan langsung lewat gambar, dialog, setting gambar, penokohan, plot alur cerita sehingga menjadi medium yang mampu secara efektif digunakan sebagai media untuk menyebarkan misi, gagasan, dan kampanye apapun pesan yang akan disebarkan atau disampaikan seseorang, lembaga atau pemerintah (Asri, 2020).

Film merupakan media komunikasi yang bersifat audio visual untuk menyampaikan suatu pesan kepada sekelompok orang yang berkumpul di suatu tempat tertentu (Baran dalam Asri 2020). Notoatmodjo (dalam Mulyati, dkk., 2015) berpendapat bahwa indera paling banyak menyalurkan pengetahuan ke dalam otak adalah mata. Kurang lebih $75 \%$ sampai $87 \%$ dari pengetahuan manusia diperoleh melalui mata. Kurang lebih 13\% sampai $25 \%$ dari pengetahuan manusia diperoleh melalui indera lain. Informasi merupakan kondisi pertama untuk suatu sikap. Bila berdasarkan informasi itu timbul perasaan positif atau negatif terhadap objek dan 
menimbulkan kecenderungan untuk bertingkah laku tertentu maka terjadilah sikap. Aspek kognitif dari empati termasuk mengambil perspektif yang melibatkan fantasi yaitu merasa empati pada karakter fiktif. Sebagai akibatnya, penonton yang berempati akan terdapat reaksi emosional terhadap kegembiraan, kesedihan, dan ketakutan yang dialami oleh seseorang atau binatang dalam sebuah buku, film, atau program televisi (Baron \& Byrne, 2017).

Penelitian ini bertujuan untuk mengetahui efektivitas penggunaan media film dalam meningkatkan empati pada narapidana kasus kekerasan seksual di Lembaga Pemasyarakatan Klas IIA Karawang.

\section{LANDASAN TEORI}

\section{Empati}

Menurut Davis (dalam Andayani, 2012) empati meliputi kapasitas afektif untuk merasakan perasaan orang lain dan kapasitas kognitif untuk memahami sudut pandang orang lain. Empati bersifat multidimensional, yang terdiri dari fantasyemphaty, perspective-taking. Emphatic concern, dan personal distress. Fantasyempathy merupakan kecenderungan seseorang untuk mengubah diri ke dalam perasaan dan tindakan dari karakter-karakter khayalan yang terdapat pada buku, film, atau permainan. Perspective-taking merupakan perilaku yang tidak berorientasi pada kepentingan diri akan tetapi pada kepentingan orang lain. Emphatic concern merupakan orientasi yang merupakan cermin dari kehangatan, perasaan simpati, kekhawatiran, dan peduli terhadap orang lain yang sedang kesusahan/ditimpa kemalangan. Personal distress merupakan kecemasan pribadi yang berorientasi pada diri sendiri serta kegelisahan dalam menghadapi situasi tidak menyenangkan yang dialami orang lain (Davis dalam Andayani, 2012).

\section{Kekerasan Seksual}

Kekerasan seksual didefinisikan sebagai setiap tindakan seksual, usaha melakukan tindakan seksual, atau tindakan lain yang ditujukan terhadap seksualitas atau organ seksual seseorang dengan adanya paksaan, tanpa memandang hubungan dengan korban dan dalam situasi apapun. Hal ini termasuk tindakan pemerkosaan, sentuhan yang tidak diinginkan, serta bentuk-bentuk non-kontak lainnya (WHO, 2021). Menurut Mboiek dan Stanko (dalam Fuadi, 2011) mendefinisikan kekerasan seksual adalah suatu perbuatan yang biasanya dilakukan laki- laki dan ditujukan kepada perempuan dalam bidang seksual yang tidak disukai oleh perempuansebab ia merasa terhina, tetapi kalau perbuatan itu ditolak ada kemungkinan ia menerima akibat buruk lainnya. Shenk dan Brown (dalam Nurani, 2014) menyebutkan bahwa penyebab kekerasan seksual disebabkan oleh dua faktor, yaitu faktor statis, dan faktor dinamis. Faktor statis merupakan karakteristik dalam diri pelaku yang tidak bisa diubah, seperti misalnya pengalaman seksual yang menyimpang, tingkah laku anti sosial, impulsivitas, sexual arousal yang tinggi, dan preokupasi seksual. Sementara faktor dinamis merupakan faktor yang responsif atau bisa diubah dengan adanya perlakuan, misalnya seperti distorsi kognitif, keterampilan sosial yang rendah, fantasi seksual yang menyimpang, dan empati yang rendah. 


\section{Film}

Film diartikan sebagai lakon, artinya film mempresentasikan sebuah cerita dari tokoh tertentu secara utuh dan berstruktur (Asri, 2020). Nursalim (2013) mengemukakan bahwa film atau gambar hidup (motion picture), yaitu serangkaian gambar diam (still picture) yang meluncur secara cepat dan tepat dan diproyeksikan sehingga menimbulkan kesan hidup dan bergerak. Film merupakan media yang menyajikan pesan audio visual dan gerak. Maka dari itu, film memberikan kesan yang impresif bagi penontonya. Menurut Saleh, dkk (2016) terdapatbeberapa tujuan film antara lain: (1) Sarana informasi, dapat menyampaikan informasi yang baik dan benar, sesuai dengan kenyataan, tidak direkayasa, masuk akal atau dibesarbesarkan; (2) Sarana pembelajaran, dapat memberikan pembelajaran yang positif sehingga dapat ditiru dan digunakan sebagai bahan ajar di sekolah dengan tujuan dapat meningkatkan pengetahuan, penanaman kognitif, psikomotrik dan pembentukan afektif; (3) Sarana hiburan, hiburan dapatmemberikan tontonan yang menghibur sekaligus dapat memasukan pesan positif baik dalam bentuk simbol, gambar atau dialog sehingga penonton baik sengaja maupun tidak sengaja memahami pesan yang disampaikan.

\section{METODE PENELITIAN}

Jenis penelitian yang digunakan dalam penelitian ini adalah penelitian eksperimen. dengan tipe quasi experiment (eksperimen semu) yang merupakan suatu bentuk eksperimen yang tidak menempatkan subjek, baik ke dalam kelompok eksperimen ataupun kelompok kontrol secara acak (nonrandom assigment). Penelitian ini melibatkan dua variable, yaitu empati sebagai variable dependen, dan media film sebagai variable independern (manipulasi). Pelaksanaan manipulasi dilakukan sebanyak satu kali yaitu dengan menayangkan film yang berjudul "27 Step of May". Desain eksperimen yang digunakan adalah one group pre-test post-test design dimana di awal penelitian, dilakukan pengukuran awal pada subjek terhadap variabel terikat yang telah dimiliki subjek, setelah diberikan manipulasi, dilakukan pengukuran kembali terhadap variabel terikat dengan alat ukur yang sama. Subjek dalam penelitian ini adalah narapidana kasus kekerasan seksual sebanyak tujuh partisipan dengan teknik pengambilan sampel yang digunakan yaitu purposive sampling. Teknik analisis data penelitian ini menggunakan statistic non-parametric yaitu uji wilxocon. Hal tersebut dikarenakan data tidak berdistribusi normal dan sampel kurang dari 30.

Penelitian diawali dengan pengukuran awal (pre-test) dengan menggunakan skala interpersonal reactivity index (IRI) terhadap subjek sebelum diberikan perlakuan. Setelah dilakukan pengukuran awal, kemudian diberikan perlakuan berupa menonton tayangan film bertema penyintas kekerasan seksual yang berjudul 27 Step of May. Setelah perlakuan diberikan, kemudian dilakukan pengukuran kembali (post-test) serta memberikan debriefing (penjelasan singkat) mengenai kesimpulan penelitian kepada subjek dan menginformasikan kepada subjek penelitian apabila terjadi dampak yang buruk, peneliti akan mengambil langkah-langkah untuk mengurangi dampak buruk tersebut dengan melakukan kerja sama dengan pihakUnit Layanan Psikologi Universitas Buana Perjuangan Karawang. 


\section{HASIL DAN PEMBAHASAN}

\section{Hasil}

Pelaksanaan Penelitian

a. Sesi pertama (pre-test)

$\begin{array}{ll}\text { Hari } & : \text { Senin \& Jumat } \\ \text { Tanggal } & : \text { 26 Juli \& 30 Juli } 2021 \\ \text { Tempat } & : \text { Ruangan Bimaswat } \\ \text { Jam } & : 09.00-12.00\end{array}$

Pada sesi pertama bertujuan untuk memperoleh hasil pengukuran sebelum perlakuan (pre-test) pada tujuh narapidana yang menjadi partisipan dalam penelitian ini. Narapidanatersebut dipanggil satu per satu ke ruangan bimaswat untuk diminta kesediaannya dalam mengisi kuesioner pre-test. Pada hari pertama tanggal 26 Juli 2021, peneliti bertemu dengan tiga narapidana yang bersedia mengisi kuesioner pre-test. Peneliti memperkenalkan diri dan menjelaskan terkait tujuan pertemuan. Lalu, peneliti meminta kesediaan partisipan untuk mengisi kuesioner, dan apabila bersedia peneliti memberikan kuesioner pre-test untuk diisi oleh partisipan. Pada hari kedua tangal 30 Juli 2021, peneliti bertemu dengan lima narapidana yang bersedia mengisi kuesioner pre-test dengan tahapan yang sama.

b. Sesi kedua (treatment dan post-

$\begin{array}{ll}\text { test)Hari } & : \text { Selasa } \\ \text { Tanggal } & : \text { 10 Agustus 2021 } \\ \text { Tempat } & : \text { Aula Lembaga Pemasyarakatan Klas IIA } \\ \text { KarawangJam } & : 09.00-12.00\end{array}$

Pada sesi kedua yaitu pemberian perlakuan (treatment) menonton film dan pengukuran setelah perlakuan (post-test) bertujuan agar pertisipan memahami proses perlakuan (treatment) yang akan dilakukan, memperoleh hasil setelah perlakuan (post-test), dan partispan memahami pentingnya empati dalam kehidupan sehari-hari. Sebelum dimulai, peneliti dibantu oleh pihak Lapas mempersiapkan alat-alat untuk penayangan film. Setelah semua partisipan berkumpul di aula, peneliti memperkenalkan diri dan menjelaskan tujuan pertemuan. Lalu, peneliti meminta kesediaan partisipan untuk terlibat dalam sesi kedua, dan meminta partisipan untuk mengisi informed consent. Peneliti menjelaskan terkait proses perlakuan (treatment) yang akan dilakukan serta menjelaskan empati secara garis besar kepada partisipan. Lalu, peneliti menayangkan film 27 Step of May, dan setelah penayangan film selesai, peneliti meminta partisipan untuk mengisi kuesioner post-test. Kemudian, peneliti melakukan debriefing kepada partisipan apabila terjadi dampak buruk, peneliti akan mengambil langkah-langkah untuk mengurangi dampak tersebut. Setelah itu, peneliti mengapresiasi keterlibatan partisipan dalam penelitian, dan menutup keseluruhan pertemuan. 
Hasil pre-test dan post-test subjek penelitian

Tabel 1. Hasil Pre-test dan Post-test

\begin{tabular}{cccccc}
\hline No & Nama & Pre-test & Post-test & Beda Skor & Ket \\
\hline 1 & JF & 67 & 73 & 6 & MENINGKAT \\
2 & HT & 79 & 82 & 3 & MENINGKAT \\
3 & K & 76 & 81 & 5 & MENINGKAT \\
4 & D & 82 & 83 & 1 & MENINGKAT \\
5 & DS & 71 & 81 & 10 & MENINGKAT \\
6 & AK & 71 & 81 & 10 & MENINGKAT \\
7 & K & 73 & 83 & 10 & MENINGKAT \\
\hline
\end{tabular}

Uji normalitas

Tabel 2. Uji Normalitas

\begin{tabular}{|c|c|c|c|c|c|c|}
\hline \multicolumn{7}{|c|}{ Tests of Normality } \\
\hline & \multicolumn{3}{|c|}{ Kolmogorov-Smirnov $^{\mathrm{a}}$} & \multicolumn{3}{|c|}{ Shapiro-Wilk } \\
\hline & Statistic & df & Sig. & Statistic & df & Sig. \\
\hline Pre-test & .159 & 7 & .200 & .968 & 7 & .881 \\
\hline Post-test & .406 & 7 & .001 & .679 & 7 & .002 \\
\hline
\end{tabular}

Berdasarkan hasil analisis dengan menggunakan uji normalitas shapiro-wilk dengan bantuan SPSS 24.0 for windows, diketahui bahwa data tidak berdistribusi normal. Hasil uji normalitas pada data pre-test diperoleh nilai Sig. sebesar 0.881 > 0.05 yang berarti data pre- test berdistribusi normal. Namun demikian, hasil uji normalitas pada data post-test diperoleh nilai Sig. sebesar $0.002<0.05$ yang berarti data post-test tidak berdistribusi normal. Dengan demikian dapat disimpulkan bahwa hasil uji normalitas secara keseluruhan data tidak berdistribusi normal.

Berdasarkan hasil analisis perhitungan pada skor pre-test dan post-test diketahui bahwasetiap subyek mengalami peningkatan skor.

Uji hipotesis

Tabel 3. Uji Hipotesis

\begin{tabular}{lr}
\hline \multicolumn{2}{c}{ Test Statistics $^{\mathbf{a}}$} \\
\hline & Post-test - Pre-test $^{\mathrm{b}}$ \\
\hline $\mathrm{Z}$ & $-2.384^{\mathrm{b}}$ \\
Asymp. Sig. (2-tailed) & .017 \\
\hline
\end{tabular}

Berdasarkan tabel diatas, diperoleh nilai Sig. sebesar $0.017<0.05$, yang berarti $\mathrm{H} 0$ ditolak, Ha diterima. Hal ini memberikan makna bahwa media film efektif dalam meningkatkan empati pada narapidana kasus kekerasan seksual di Lembaga Pemasyarakatan Klass IIA Karawang. 


\section{Pembahasan}

Berdasarkan analisis uji hipotesis menggunakan statistic non parametric dengan uji wilcoxon didapatkan hasil nilai Sig. sebesar $0.017<0.05$ hal ini berarti bahawa media film terbukti efektif dalam meningkatkan empati. Sejalan dengan pendapat yang diungkapkan oleh Effendy (dalam Oktavianus, 2015) film berperan sebagai sebuah sarana yang ampuh sekali, bukan saja untuk hiburan, tetapi juga untuk penerangan dan pendidikan. Film mempunyai suatu dampak tertentu terhadap penonton, dampak-dampak tersebut dapat berbagai macam seperti dampak psikologis, dan dampak sosial. Senada dengan hal tersebut, Hesley dan Hesley (dalam Rosyida, 2016) mangatakan bahwa penggunaan film sebagai media terapi untuk membuka hambatan emosional pada individu ternyata efektif.

Baron dan Byrne (dalam Rosyida, 2020) mengemukakan bahwa seseorang akan merasaempati pada karakter fiktif sebagaimana kepada korban pada kehidupan nyata. Karakter fiktif tersebut dapat berupa peran tokoh dalam suatu film. Film dapat memberikan efek positif padaorang yang melihatnya dan empati merupakan suatu hal yang positif dengan kata lain meningkatkan empati adalah suatu hal yang positif. Film sebagai media pembelajaran sekaligus proses sosialisasi dimana nilainilai disampaikan kemudian diserap oleh khalayak dan akan terjadi proses internalisasi yang kemudian menjadi sikap seseorang (Asri, 2020). Penggunaan film lebih mudah dipahami dibandingkan dengan kata-kata (Demir dalam Rosyida, 2020). Sebagaimana pendapat yang diutarakan oleh Davis (dalam Andayani, 2012), pada dimensi empati yaitu fantasy-emphaty seseorang cenderung untuk mengubah diri ke dalam perasaan dan tindakan dari karakter-karakter khayalan yang terdapat pada buku, film, atau permainan. Dimensi ini melihat perilaku individu menempatkan diri dan hanyut dalam perasaan dan tindakan orang lain.

Selain itu, Notoatmodjo (dalam Mulyati, dkk., 2015) berpendapat bahwa indera palingbanyak menyalurkan pengetahuan ke dalam otak adalah mata. Kurang lebih $75 \%$ sampai $87 \%$ dari pengetahuan manusia diperoleh melalui mata. Kurang lebih $13 \%$ sampai $25 \%$ daripengetahuan manusia diperoleh melalui indera lain. Informasi merupakan kondisi pertama untuk suatu sikap. Bila berdasarkan informasi itu timbul perasaan positif atau negatif terhadapobjek dan menimbulkan kecenderungan untuk bertingkah laku tertentu maka terjadilah sikap. Tidak dapat dipungkiri, salah satu penyebab yang mendorong pelaku melakukan kekerasan seksual adalah adanya empati yang rendah (Shenk dan Brown dalam Nurani, 2014). Bahkan umumnya pelaku yang melakukan kejahatan seperti pemerkosaan, pedofilia, dan banyak tindak kejahatan rumah tangga, tidak mampu berempati (Goleman, 2018). Hal tersebutdapat diubah apabila diberikan perlakuan (Shenk dan Brown dalam Nurani, 2014). Berdasarkan hasil penelitian yang telah dilakukan, setelah diberikan perlakuan berupa menonton film menunjukkan adanya peningkatan empati pada narapidana kasus kekerasan seksual. Dengan adanya kemampuan berempati, seseorang mampu untuk memahami dan mengerti perasaan orang lain sehingga dapat merasakan apa yang dialami oleh orang lain, serta mampu memahami dan mengendalikan diri sendiri (Goleman dalam Solekhah, Atikah, \& Istiqomah,2018). Ia juga akan mampu untuk lebih toleran, ramah, serta mempunyai sifat humanistik terhadap orang lain (Rogers dalam Sutanti, 2015). Dan dapat meningkatkan hubungan sosial dilingkungan masyarakat (Wardhati dalam Citra, 2020). 


\section{KESIMPULAN}

Berdasarkan hasil penelitian dan analisa data yang telah dilakukan pada tujuh partisipan menunjukkan bahwa nilai Sig. sebesar $0.017<0.05$, yang berarti $\mathrm{H} 0$ ditolak, Ha diterima. Sehingga dapat disimpulkan bahwa media film efektif dalam meningkatkan empati pada narapidana kasus kekerasan seksual di Lembaga Pemasyarakatan Klas IIA Karawang.

Dengan berdasar hasil penelitian yang telah dilakukan, dapat diajukan saran sebagai berikut:

a. Bagi subjek diharapkan dapat memahami makna yang terkandung dari film yang telah ditayangkan sehingga dapat lebih berempati terhadap orang lain. Selain itu, mampu mengembangkan pengetahuan dan wawasan dengan menonton tayangan yang mengandungnilai-nilai empati terhadap orang lain.

b. Bagi Lembaga Pemasyarakatan diharapkan dapat menjadi masukkan dengan menjadikan film sebagai bahan pertimbangan untuk meningkatkan empati pada narapidana kasus kekerasan seksual.

Bagi peneliti selanjutnya diharapkan dapat dijadikan sumber referensi untuk penelitian- penelitian selanjutnya terkait media film dan empati pada narapidana kasus kekerasan seksual. Film yang digunakan dalam penelitian ini belum sempurna, diharapakan peneliti lain dapat mempertimbangkan durasi film yang akan dipilih. Selain itu, peneliti selanjutnya disarankan setelah dilakukan perlakuan, dapat dilakukan wawancara singkat sebagai data tambahan terkait film yang ditayangkan. Lalu, dapat menggunakan desain dua kelompok, dan menggunakan tema-tema psikologis lain untuk dilakukan eksperimen dengan menggunakan media film.

\section{REFERENSI}

Andayani, T. R. (2012). Studi meta-analisis: Empati dan bullying. Buletin Psikologi, 20(1), 36-51.

Asri, R. (2020). Membaca film sebagai sebuah teks: Analisis isi film "Nanti Kita Cerita Tentang Hari Ini (NKCTHI)". Jurnal Al Azhar Indonesia Seri Ilmu Sosial, 1(2),m74-86.

Auliyah, A., \& Flurentin, E. (2016). Efektivitas penggunaan media film untuk meningkatkn empati siswa klas VII SMP. Jurnal Kajian Bimbingan dan Konseling, 1(1), 19-26.

Baron, R. A., \& Byrne, D. (2017). Psikologi Sosial Jilid 2. Alih Bahasa: Ratna Djuwita. Edisikesepuluh. Jakarta: Erlangga

Catatan Kekerasan terhadap Perempuan. (2020). Komnas Perempuan: Jakarta.

Citra, Y. (2020). Efektivitas teknik cinematherapy untuk meningkatkan empati remaja di Desa Malela Kecamatan Suli. Skripsi. Program Studi Bimbingan dan Konseling Islam Institut Agama Islam Negeri Palopo.

Fuadi, M. A. (2011). Dinamika psikologis kekerasan seksual: Sebuah studi fenomenologi. Jurnal Psikologi Islam, 8(2), 191-208.

Goleman, D. (2018). Kecerdasan emosional. Alih Bahasa: T. Heryana. Jakarta: PT. GramediaPustaka Utama.

10 Psikologi Prima |e-ISSN : 2598-8026 | DOI : 10.34012 
Mubina, N. (2017). Konsep diri pada perempuan korban kekerasan seksual di Karawang.

Psychopedia Jurnal Psikologi Universitas Buana Perjuangan Karawang, 2(2), 1936.

Mulyati, S., Suwarsa, O., \& Arya, I. F. (2015). Pengaruh film terhadap sikap ibu pada deteksi dini kanker serviks. Jurnal Kesehatan Masyarakat, 11(1), 1624.

Nurani, R. A. (2014). Efektivitas rational emotive behavior (REBT) dalam meningkatkan victim emphaty pada remaja pelaku kekerasan seksual. Tesis. Universiras Indonesia.

Nursalim. (2013). Pengembangan media bimbingan dan konseling. Jakarta: Indeks.

Oktavianus, H. (2015). Penerimaan penonton terhadap praktek eksorsis di dalam film conjuring. Jurnal E-Komunikasi, 3(2), 1-12.

Parman, T. L., Asmarany, A. I., \& Saputro, M. (2019). Empati dan perilaku prososial pada mahasiswa pengguna kereta rel listrik. Jurnal Psikologi, 12 (1), 1-10.

Reza, F. A., \& Widyana, R. (2019). Pelatihan empati untuk meningkatkan pemaafan pada mahasiswi korban kekerasan dalam hubungan pacaran. Anfusina: Journal of Psychology, 2(2), 147-158.

Rosyida, A. H. (2020). Efektivitas terapi film dalam meningkatkan empati. Psikoborneo, 8(2),211-220.

Simatupang, M. (2020). Budaya organisasi sebagai variabel predictor terhadap organizational citizenship behavior pada karyawan koperasi, Psychopedia Jurnal Psikologi Universitas Buana Perjuangan Karawang, 5(1), 8-19.

Saleh, R. Y., Arya, I. F., \& Afriandi, I. (2016). Film yang efektif sebagai media promosi kesehatan bagi masyarakat. JSK, 2 (2), 70-78.

Solekhah, A. M., Atikah, T. P., \& Istiqomah, M. (2018). Faktor-faktor yang mempengaruhi sikap empati terhadap perilaku prososial pada anak Sekolah Dasar. Prosiding Seminar Nasional "Penguatan Pendidikan Karakter pada Siswa Dalam Menghadapi TantanganGlobal”, 86-90.

Sulaeman. (2021, Maret). KemenPPPA: Kasus pelecahan seksual adalah fenemona gunung es. 